UDC: 351

DOI: https://doi.org/10.32689/2617-

2224-2019-17-2-95-107

Kifriak Oleksandr Nikolaevich, graduate student of the Interregional Academy of Personnel Management, deputy head, Office of the State Architectural and Construction Inspectorate in Chernivtsi region, 58001, Chernivtsi, Str. P. Celana, 11, tel.: +38 (050)675 22 41, e-mail: sankif@ukr.net

ORCID: 0000-0001-9724-6557

Кіфряк Олександр Миколайович, аспірант Міжрегіональної Академії управління персоналом, заступник начальника, Управління Державної архітектурно-будівельної інспекції у Чернівецькій області, 58001, м. Чернівиі, вул. П. Целана, 11, тел.: +38 (050) 67522 41, e-mail: sankif@ukr.net

ORCID: 0000-0001-9724-6557

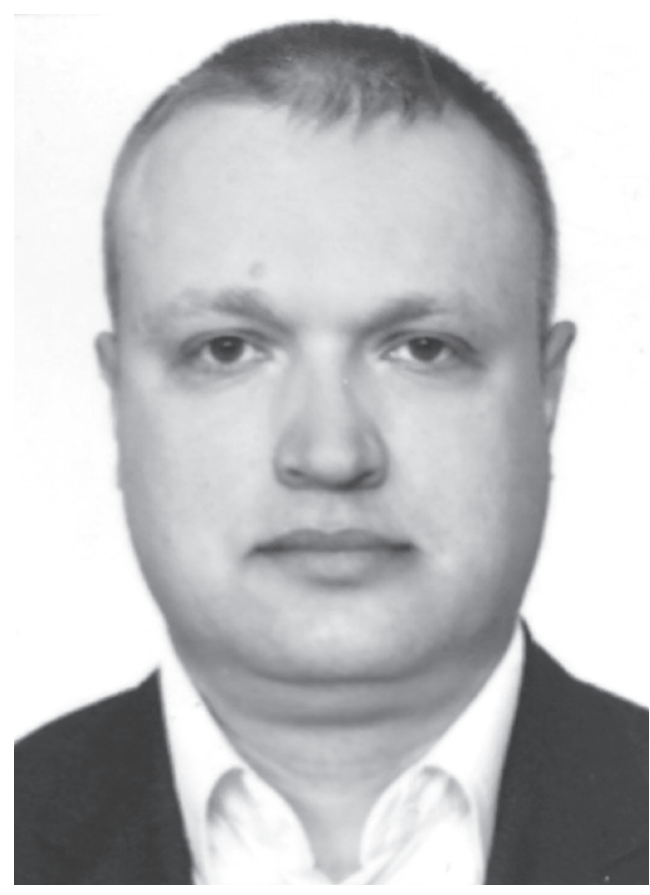

Кифряк Александр Николаевич, аспирант Межрегиональной Академии управления персоналом, заместитель начальника, Управления Государственной архитектурно-строительной инспекции в Черновицкой области, 58001, г. Черновиљ, ул. П. Целана, 11, тел.: +38 (050) 67522 41, e-mail: sankif@ukr.net

ORCID: 0000-0001-9724-6557

\title{
ON THE CONCEPT OF THE CONCEPT OF TRANSPARENCY OF FUNCTIONING BY THE PUBLIC AUTHORITY
}

Abstract. Scientific approaches to the implementation of the concept of transparency in the field of public policy are revealed, when processes of enhancing the role and importance of information both for society as a whole and in the life of every citizen occur in the globalization space. An etymological analysis of the terms "concept" and "transparency" is made. The conceptual definition of the "concept of transparency", the basic mechanisms and tools for the implementation of these ideological reference points in the activities of the public administration system as a whole and in certain spheres of public life are defined. The scientific approaches to the definition of the concepts "concept" and "transparency" are investigated, on the basis of which an own definition of the concept "concept of transparency" is provided. The conceptual features of the principle of public policy transparency have been reviewed. The main constituent elements of the principle of transpa- 
rency are highlighted, in particular, its content is defined as the interaction of management bodies with its objects, providing feedback in the process of exercising authority to exercise management functions. The role of the public in ensuring the transparency of public authority is defined. It is concluded that access to information is a prerequisite of public control and the main element of the development of civil society. The issue of increasing the attention of public initiative centers to the concept of public policy transparency has been investigated. It was noted that solving the problems of transparency of the entire public administration system is one of the key areas in the process of further approval in Ukraine of democratic principles in terms of constitutional reform, rooting of civilized norms of the state for the benefit and protection of human rights and citizen.

Keywords: transparency concept; public authority; government; functioning; principle, civil society; public administration system; constitutional reform.

\section{ДО ПИТАННЯ ПРО КОНЦЕПЦІЮ ПРОЗОРОСТІ ФУНКЦІОНУВАННЯ ОРГАНІВ ПУБЛІЧНОЇ ВЛАДИ}

Анотація. Розкрито наукові підходи до реалізації концепції прозорості у сфері державної політики, коли у глобалізаційному просторі відбуваються процеси посилення ролі та значення інформації як для суспільства в цілому, так і в житті кожного громадянина. Зроблено етимологічний аналіз термінів “концепція” та “прозорість”. Окреслено понятійно-категорійні питання визначення “концепції прозорості”, основні механізми та інструменти впровадження зазначених ідеологічних орієнтирів у діяльність системи органів публічної влади у цілому та в окремих сферах життєдіяльності суспільства. Досліджено наукові підходи до визначення понять “концепція” та “прозорість" на основі чого надано власне визначення поняття “концепція прозорості”. Здійснено розгляд концептуальних особливостей принципу прозорості державної політики. Виділено основні складові елементи принципу прозорості, зокрема, визначено його зміст як взаємодію органів управління з його об'єктами, забезпечення належного зворотного зв'язку у процесі здійснення повноважень з реалізації управлінських функцій. Окреслено роль громадськості у забезпеченні прозорості функціонування публічної влади. Зроблено висновок, що доступ до інформації є передумовою публічного контролю і головним елементом розвитку громадянського суспільства. Досліджено питання зростання уваги центрів громадських ініціатив до питання концепції прозорості державної політики. Наголошено на тому, що розв'язання проблем прозорості усієї системи державного управління є одним із ключових напрямів у процесі подальшого утвердження в Україні демократичних принципів в умовах конституційного реформування, укорінення цивілізованих норм функціонування держави на благо та захист прав людини та громадянина.

Ключові слова: концепція прозорості; орган публічної влади; державне правління; функціонування; принцип, громадянське суспільство; система державного управління; конституційне реформування. 


\section{К ВОПРОСУ О КОНЦЕПЦИИ ПРОЗРАЧНОСТИ ФУНКЦИОНИРОВАНИЯ ОРГАНОВ ПУБЛИЧНОЙ ВЛАСТИ}

Аннотация. Раскрыто научные подходы к реализации концепции прозрачности в сфере государственной политики, когда в глобализационном пространстве происходят процессы усиления роли и значения информации как для общества в целом, так и в жизни каждого гражданина. Сделано этимологический анализ терминов “концепция” и “прозрачность”. Обозначены понятийно-категориальные вопросы определения “концепции прозрачности”, основные механизмы и инструменты внедрения указанных идеологических ориентиров в деятельность системы органов публичной власти в целом и в отдельных сферах жизнедеятельности общества. Исследованы научные подходы к определению понятий “концепция” и “прозрачность” на основе чего предоставлено собственное определение понятия “концепция прозрачности”. Осуществлено рассмотрение концептуальных особенностей принципа прозрачности государственной политики. Выделены основные составляющие элементы принципа прозрачности, в частности, определено его содержание как взаимодействие органов управления с его объектами, обеспечения обратной связи в процессе осуществления полномочий по реализации управленческих функций. Определена роль общественности в обеспечение прозрачности функционирования публичной власти. Сделан вывод, что доступ к информации является предпосылкой публичного контроля и главным элементом развития гражданского общества. Исследован вопрос роста внимания центров общественных инициатив к вопросу концепции прозрачности государственной политики. Отмечено, что решение проблем прозрачности всей системы государственного управления является одним из ключевых направлений в процессе дальнейшего утверждения в Украине демократических принципов в условиях конституционного реформирования, укоренения цивилизованных норм функционирования государства на благо и защиту прав человека и гражданина.

Ключевые слова: концепция прозрачности; орган публичной власти; государственное правление; функционирование; принцип, гражданское общество; система государственного управления; конституционное реформирование.

Problem statement. Today our state goes through hard times, for the first time in its recent history having faced with armed aggression from the enemy, which considerably surpasses Ukraine both in military and political, and in economic and informational terms.
Under these conditions, the most critical task for domestic legal science is to find new conceptual solutions that would give an impulse to the practice of government on protecting the sovereignty and territorial integrity of Ukraine. The convergence of national legal system with legal systems of mo- 
dern European countries based on common principles and approaches and, thus, formation of the unified European legal system; problems and prospects of legal regulation of both public and private spheres of social life from the perspective of national legislation as well as legal experience of EU countries should become the main guiding principles for modern legal experts.

Recently, the problem of transparency is increasingly mentioned when characterizing various social institutions in the context of democratization of state and social life in Ukraine. This is largely connected with the study of international standards and adaptation of experience of EU countries, in which transparency is recognized as one of the principles following the idea of statement of legal community [1, p. 43].

Degree of scientific development. The problem of transparency of public institution functioning was studied by foreign scientists such as M. Di Niz [2], J. Lodge [3], P. Craig [4] and A. Santini [5]. Equal attention to the issues of transparency of public authority activities are paid by Ukrainian and Russian scientists such as S. Holovatyi [6], A. Chuklinov [7], I. Berezovska [8], I. Ibrahimova [9], V. Melnychenko [10, 11], N. Hudima [12], J. Balkin [13], and I. Hrytsiak [14]. At the same time, the issue of implementing the conception of transparency in the public administration system of Ukraine is not adequately reflected in the works of domestic scientists. In particular, we do not find a semantic analysis of the concept of "conception of transparency" and its details in any research study. The studies of issues of transparency of public authorities are only of fragmentary na- ture and do not allow to fully disclose the significance of conception of transparency as a basic principle of creation of the public administration system of Ukraine.

Purpose of this article is to try to disclose the etymological analysis of the terms "conception" and "transparency" as well as to consider the conceptual features of the principle of state policy transparency.

Statement of basic materials. The term "conception" comes from Latin "conceptio", which means to comprehend, to perceive. The conception mainly refers to system of views, concepts about these or those phenomena or processes, way of their understanding and interpretation; fundamental idea of any theory, main intention; idea or plan of new, original understanding; constructive principle of artistic, technical and other activities [15].

The study of the conception as knowledge has its origin in the era of European Middle Ages, in particular, this was reflected in the work of P. Abelard [16], who studied the conception as a concept synthesizing three ways of the soul: as past-oriented act of memory, future-oriented act of representation and present-oriented act of judgment.

Since the second half of XX century, the conception has been understood as the identification of social and cultural context of natural and humanitarian knowledge. These considerations are of gnoseological relevance and as of today.

Thus, in our opinion the conception should be understood as a complex of key provisions or thought affirmations that allow keeping the research direction. This is a kind of compass in the movement of thought. 
Little Oxford English Dictionary connects the term "transparency" first of all with the physical phenomenon specific to fluid, gemstones, film, and, then, with the term "clarity", which means clearness, ease of perception [17].

Cambridge Learner's Dictionary defines "transparency" as, in particular, the universal characteristic of an object to be transparent, and as clarity and clearness [18]. The domestic Large Explanatory Dictionary understands the term "transparency" as the property and condition of something transparent, and in data processing systems as the intermediate interaction means, the application of which is invisible to the user, the property of physical connection of protocol or program to transmit the information encoded in any way without any changes in it [19].

Undoubtedly, the principle of transparency is applied to all social institutions, therefore, it is reasonable to disclose the etymological content of the term "transparency" in terms of its social significance, which can be found in the encyclopedic edition "Sociology" [20].

In the article of D. Halkin "Virtual discourse on the postmodern culture", the transparency is defined as one of the main concepts of modern theory of the information-oriented society, postmodern social theory and sociology characterizing the influence of information and media on the mechanisms of social organization. According to D. Halkin, this phenomenon is intended to provide an opportunity for comprehensive representation of social structures and individuals in the common information field and provides, first of all, the avai- lability, speed and high degree of information structuring, convenience of its conversion into various, easy-to-understand formats and existence of constant feedback [13, p. 21].

The understanding of openness and transparency as rules on which the activities of public authorities should be based, or as principles, the observance of which will promote the creation of the system of public authorities ensuring the implementation of common values of real democracy, which currently is almost unexplored.

The large majority of domestic scientists see the implementation of principles of openness and transparency in informing the public about functional separation of duties and division of powers between public authorities.

I. Ibrahimova understands the principle of transparency as ensuring the dialogue with the public at all stages of decision-making and permanent access to complete, clear information on the activities of public authorities and their officials in accordance with the current legislation [9].

V. Melnychenko interprets the principle of transparency as ability of the state to ensure a high level of awareness of citizens and their communities on material and procedural side of government and administrative activities, awareness of citizens and their communities on the planned decisions of public authorities and how they will be implemented [10, p. 51].

The principle of transparency as a value guide of the European Union law has also been widely studied by experts of public law. Thus, O. Vitvitska and H. Horning, authors of the book "European Union Law", among the functio- 
nal principles of European Union law define also the principle of protection of trust and legal security, the content of which also includes the transparency of public institutions of the states [22, p. 52].

In the textbook "Introduction to the European Union Law" [23] of Kernza V., the principle of transparency of these institutions is determined as the principle of construction and functioning of the institutional structure of the European Union.

In the manual edited by R. A. Petrov [24], the authors adhere to the Western European approach to distinguishing only general principles of the European Union law. According to the authors, the general principles of law include principles of respect for fundamental human rights, proportionality, equality or non-discrimination, legal completeness, transparency and compliance with procedural rights, subsidiarity.

So, summarizing the above, we can conclude that the domestic scientists came to common provisions on content of the principle of transparency with regard to the following statements: 1) openness and transparency of the activities of public authorities are understood as possibility of the person to obtain information not only concerning himself, but also on social, political, state and regional issues concerning the unlimited access to all types of information, documents, activities and motives; 2) openness and transparency of public authorities are not identical concepts. The openness is not transparent yet, but only leads to it. The transparency of the activities of public authorities is the result of process of openness. The openness of public authorities results in full transparency of their activities. The transparency of public authorities is defined as a condition, which is characterized by full "transparency" of all directions and results of their activities; 3 ) based on constitutional structure of government in Ukraine, the principle of government openness can be defined as its duty to ensure the possibility of free access of citizens to administration of the state affairs.

As we have noticed, none of the domestic scientists studies the conception of transparency of public institutions, but only focuses on doctrinal determination of the principle of transparency and openness of public power.

However, it is impossible to say that Ukrainian science is outdated and does not pay attention to the study of these issues. Separate aspects of conception of transparency are interpreted in the most unexpected forms of national science of law.

So, in 2008, Hudimova N. V. defended the dissertation for degree of Candidate of Sciences in Public Administration on the topic "Principles of openness and transparency in the activities of public authorities of Ukraine" [12]. The dissertation was devoted to the problems of evolutionary development of implementation of the principles of openness and transparency in the activities of public authorities and their influence on administrative activity condition in the context of processes of democratization of Ukrainian society. The scientist has theoretically substantiated the necessity of the principles of openness and transparency as components of public administration and, at the same time, objective cha- 
racteristics of improvement of its components.

Of particular note is the fundamental monograph "Ukrainian Revolution of Dignity, Russian Aggression and International Law" prepared by collaborative writing team headed by professor O. Zadorozhnii [25]. Both in his previous monograph "Genesis of International Legal Identity of Ukraine" [1] and in the monograph of 2016, Zadorozhnii O. V. defines the concept of transparency of public institutions as the main prerequisite for recognition of legal identity of Ukraine as an equal member of the European Union. In addition, according to the scientist, the transparency of the activities of public authorities was one of the ideals of the Revolution of Dignity.

As for the western doctrine, it should be noted that although there are special monographic studies of the principles of the European Union law [26], they are devoted to the principles of the $\mathrm{Eu}^{-}$ ropean Union law in general without paying special attention to the principle of transparency of administration or conception of transparency.

During the study of this topic, we found a quite interesting fact. The conception of transparency did not become a part of such conglomerate of scientific works of domestic legal experts, however, it is nearly the most relevant activity of non-governmental initiative centers and research institutes of young financial and political scientists.

Let's take the manual of Taran V. V. and Tarnai V. A. "Functioning of the Unified Web Portal for Public Funds Use" [27] as an example. The guidance manual is extremely filled with practical aspects of implementing the pub- lic idea about maximum openness of information on public funds use. The main purpose of the publication was to ensure the effective public funds use and increase in the level of population awareness.

Such transparency of the process of public funds disbursing minimizes corruption risks and will facilitate improving of business environment in the country.

In particular, participants of the International Scientific Congress "Information Society in Ukraine", held on October 29, 2013 in Kyiv, in their decision noted that E-government can change the very nature of power and make it more transparent and controlled by the public, as well as it creates conditions for accelerating business development, improving the investment environment, economic growth, and, most importantly, ensuring the real participation of citizens in political processes. It was noted that implementing the E-government requires creation of brand new organizational forms of the activities of public authorities, ensuring interaction with citizens and business entities by providing broad access to state information resources and providing the administrative services [28].

The Eastern European Democratic Center with assistance of Batory Foundation issued a publication documenting the examples of the appeal of Belarusian non-governmental organizations for the purpose of social problems solving. Thanks to the book "Representation of Public Interests", we will be able to find out how social issues, including issues of ensuring the transparency of public institutions, were solved by 
means of a public initiative in the Republic of Belarus.

A number of scientific studies in the field of implementing the conception of transparency at all levels of public administration are currently being carried out on the topics of integrated scientific project "Public Administration and Local Self-Government" that is implemented by the Institute of Public Administration and Local Self-Government of the National Academy for Public Administration at the President of Ukraine. The scientific work of the Institute is directed at scientific support of educational and vocational and professional training programs, as well as public reforms.

According to Ch. Taylor, the minimum civil society is equal to the existence of state-independent non-governmental organizations, or as they now say - the "third sector".

Now, when the country is transforming and moving to a new level of development, the public activity became more visible. That is why the sphere of implementing the conception of transparency of public institutions did not evade the wide public initiatives.

Now almost every second person understands who the public figure is, as these were the terrible events that accompanied the Revolution of Dignity that made everyone, who is indifferent to the future of the country and own future, to mobilize, unite and devote their time to our society.

The special attention should be paid to the experience of the youth organization "New Generation" with initiative groups in the sphere of ensuring the implementation of the principle of transparency in all spheres of public life of Ukrainian people. The manual "Beginner's Guide to Public Activities" is a collection of recommendations for civil society organizations and initiative groups in the sphere of ensuring the transparency of administration of any sphere of society being [29].

Let's disclose several outstanding moments that are highlighted in the collection of recommendation on the conception of transparency of public institutions: *the word "vriaduvannia" or "uriaduvannia" (governance) is a typical Ukrainian word, which has long been associated with a transparent decision-making process involving all members of the community (veche, village meeting, etc.). For many Ukrainians this word meant the democracy and accountability of every voice; it designated the long-standing traditions of local self-government in Ukraine. However, as there is no absolute equivalent for this word in Russian, in the Soviet times in the Ukrainian Dictionary it was marked as archaism and it was recommended to use the synonym - to administer; ${ }^{*}$ In the theory of political science, the concept of administration means the process of implementing the power in the society, way of its implementation to meet the needs and requirements of citizens. One of the features characterizing the democratic nature of governance process in the state is application of principles of good governance consisting of openness and transparency of decisionmaking by public authorities and local self-government, accountability to citizens (as they are the source of power), broad involvement of citizens in the decision-making process; *Governance as clear and transparent decision-making 
process, enables any authority to use resources and power in a reported manner, based on common values.

In turn, the experts of the European Foundation Center proposed four principles of effective work of any organization (in this case society is also considered as an organized community). Among these principles, the principle of transparency is determined as the second principle in the hierarchy. It means the coverage of information on receipts, objectives and results of the organization.

As the activities of mass media, civil society and public organizations, political parties and business sector cannot be regulated completely and exclusively by law (as the comprehensive regulation can be considered as manifestation of non-democratic nature and impediment to freedom of meeting, business conduct and self-expression), the greater efficiency could be achieved through mechanisms of sectoral self-regulation and internal rules. Despite the ability to make their financial statements transparent and to adopt internal codes of ethics and ensure their observance, the public organizations do not show enough efforts in this direction. Since 2010 , the number of media signing the sectoral codes of ethics remains insignificant, and cases of internal codes of ethics, especially among print media owned by publishing corporations, are rare.

The Financial Action Task Force on Money Laundering (FATF) approved the transparency standards to prevent the abuse by corporate entities. This sphere of legal relations, undoubtedly, has a significant influence in ensuring the transparency of legal system of
Ukraine. According to FATF recommendations, the states are obliged to provide reliable, accurate and up-todate information on measures of verification of corporate entities concerning origin of their financial resources and to provide the banking transaction monitoring system and application of sanctions if necessary [30].

Conclusions. Thus, the declarative nature remains one of the reasons for ineffective functioning of the principle of transparency in the activities of public authorities, despite their declaration in numerous legislative and regulatory acts. To a large extent, this is a result of absence in the current legislation of the rules of administrative responsibility of officials of public authorities for violation of these rules. The degree of scientific study of the conception of transparency is rather small and is limited only to determination of the principle of transparency of public administration without studying the paradigm nature of transparency of social institutions.

In our opinion, the conception of transparency of the activities of public institutions should be understood as a set of measures aimed at ensuring the openness and transparency in their activities by developing the elements that would create the integrity of these rules, interact with each other and influence on the interaction of administrative authorities with its objects, as well as ensure the adequate feedback during exercising powers to implement the administrative functions.

\section{REFERENCES}

1. Zadorozhnii O. (2014). Heneza mizhnarodnoi pravosubiektnosti Ukrainy 
[Genesis of International Legal Personality of Ukraine]. Kyiv: K.I.S. [in Ukrainian].

2. De Nes M. (2015). The ESM and the Principle of Transparency. Perspectives on Federalism, 7, 128-141 [in English].

3. Lodge J. (1994). Transparency and Democratic Legitimacy, Journal of Common Market Studies, XXXII(3), 343-368 [in English].

4. Craig P. (2012). EU Administrative Law. Oxford: Oxford University Press [in English].

5. Santini A. (2004). Il principio di trasparenza nell'ordinamento dell'Unione europea. Milano: Giuffrè [in Italian].

6. Holovatyi S. (2006). Verkhovenstvo prava. Knyha druha. Vid doktryny do pryntsypu [The Rule of Law. Vols. 2. From doctrine to principle]. Kyiv: Feniks [in English].

7. Chuklinov A.E. (2006). "Prozrachnaya" gosudarstvennaya politika: nekotorye problemy teorii i praktiki ["Transparent" state policy: some problems of theory and practice]. Vestn. Ros. un-ta druzhby narodov - Bulletin of Peoples' Friendship University of Russia, 8, 44-50 [in Russian].

8. Berezozska I. A. (2015). Kontseptsiia prozorosti v Uhodi pro asotsiatsiiu mizh Ukrainoiu ta Yevropeiskym Soiuzom [The Concept of Transparency in the Association Agreements between Ukraineand the European Union]. Pravo Ukrainy : Yurydychnyi zhurnal Law of Ukraine: Journal on Law, 8, 53-64 [in Ukrainian].

9. Ibrahimova I. M. (2002). Prozorist vlady. Osnovy zabezpechennia informatsiinoi vzaiemodii derzhavnykh orhaniv z hromadskistiu : prezentats. skhemy [Transparency of power. Fundamentals of Information Interaction of Government Authorities with the Public: Scheme Presentation]. Kyiv: PROON [in Ukrainian].
10. Melnychenko V. I. (2003). Prozorist i vidkrytist derzhavnoho upravlinnia yak chynnyky yoho stabilizatsii [Transparency and openness of public administration as factors of its stabilization]. Visn. Nats. akad. derzh. upr. pry Prezydentovi Ukrainy - Bulletin of the National Academy of Public Administration under the President of Ukraine, 4, 48-55 [in Ukrainian].

11. Melnychenko V. I. (2007). Prozorist i vidkrytist publichnoho upravlinnia yak obiekt zakonodavchoho rehuliuvannia [Transparency and openness of public administration as an object of legislative regulation]. Derzhavne upravlinnia: teoriia i praktyka - Public Administration: Theory and Practice, 1. Retrieved from http://www.nbuv. gov.ua/e-journals/DUTP/2007-1/ txts/07mviozr.htm [in Ukrainian].

12. Hudyma N. (2005). Pryntsypy vidkrytosti i prozorosti ta yikh realizatsiia u derzhavnomu upravlinni Ukrainy [Principles of Openness and Transparency and Their Implementation in the Public Administration of Ukraine]. Visn. Nats. akad. derzh. upr. pry Prezydentovi Ukrainy - Bulletin of the National Academy of Public Administration under the President of Ukraine, 3, 77-83 [in Ukrainian].

13. Balkin J. M. (1999). How Mass Media Simulate Political Transparency. digitalcommons.law.yale.edu. Retrieved from https://digitalcommons.law.yale. edu/fss_papers/259/[in English].

14. Hrytsiak I. (2004). Osnovni pryntsypy prava Yevropeiskoho Soiuzu ta yikh zastosuvannia $\mathrm{v}$ derzhavnomu upravlinni [Basic principles of the law of the European Union and their application in public administration]. Visn. Nats. akad. derzh. upr. pry Prezydentovi Ukrainy - Bulletin of the National Academy of Public Administration under the President of Ukraine, 3, 4350 [in Ukrainian]. 
15. Ryzhko V.A. (1995). Kontseptsiia yak forma naukovoho znannia [Concept as a Form of Scientific Knowledge]. Kyiv [in Ukrainian].

16. Abaelardus P. (1995). Logika "dlya nachinayushchikh” [Logica Ingredientibus]. Moscow [in Russian].

17. Compact Oxford English Dictionary of Current English. www.askoxford. com. Retrieved from http://www. askoxford.com/results [in English].

18. Cambridge Advanced Learner's Dictionary. dictionary.cambridge.org. Retrieved from http://dictionary. cambridge.org/results.asp [in English].

19. Busel V. T. (Eds.). (2005). Velykyi tlumachnyi slovnyk suchasnoi ukrainskoi movy [Great explanatory dictionary of modern Ukrainian language]. Kyiv; Irpin : Perun [in Ukrainian].

20. Gritsanov A. A., Abushenko V. L., Velkin G. M. (2003). Sotsiologiya: entsiklopediya [Sociology: Encyclopedia]. Minsk: Kn. Dom [in Russian].

21. Galkin D. (2000). Virtualnyy diskurs $\mathrm{v}$ kulture postmoderna [Virtual discourse in the culture of postmodern]. Kritika i semiotika - Criticism and semiotics, 1-2, 26-34 [in Russian].

22. Goring G., Vitvitskaya O. (2005). Pravo Evropeyskogo Soyuza [European Union Law]. Saint Petersburg: Piter [in Russian].

23. Cairns B. (2002). Vstup do prava Yevropeiskoho Soiuzu [Introduction to the Law of the European Union]. Kyiv: Znannia, KOO [in Ukrainian].

24. Petrov R. A. (Eds). (2010). Pravo Yevropeiskoho Soiuzu [European Union law]. ( $3^{\text {rd }}$ ed., rev.). Kyiv: Istyna [in Ukrainian].

25. Zadorozhnii O. (2014). Ukrainska revoliutsiia hidnosti, ahresiia RF i mizhnarodne pravo [Ukrainian Revolution of Dignity, Russian Aggression and International Law]. Kyiv: K.I.S. [in Ukrainian].
26. Foster N. (2000). EC Law. Oxford: Oxford Univ. Press [in English].

27. Taran V. V., Tarnai V. A., Maziarchuk V. M., Rozlutska A. B. (2016). Funktsionuvannia Yedynoho vebportalu vykorystannia publichnykh koshtiv (Ye-Data) [Functioning of the Single Web-Portal on the Use of Public Funds (E-Data)]. Kyiv: Tsentr politychnykh studii ta analityky [in Ukrainian].

28. Rishennia Mizhnarodnoho naukovoho konhresu "Informatsiine suspilstvo v Ukraini” (29 zhovtnia 2013 roku, m. Kyiv) [Decision of the International Scientific Congress "Information Society in Ukraine” (October 29, 2013, Kyiv)]. congress.ogp.gov.ua. Retrieved from http://congress.ogp.gov.ua/content [in Ukrainian].

29. Hliebushkina O., Kachura H. (Eds.). (2015). Porady dlia pochatkivtsiv v hromadskii diialnosti [Tips for Beginners in Public Activities]. Kherson: MO "Nova heneratsiia" [in Ukrainian].

30. Site of FATF. www.fatf-gafi.org. Retrieved from http://www.fatf-gafi.org/ [in English].

\section{СПИСОК ВИКОРИСТАНИХ ДЖЕРЕЛ}

1. Задорожній О. Генеза міжнародної правосуб'єктності України: монографія / Укр. асоц. міжнар. права, Ін-т міжнар. відносин Київ. нац. ун-ту ім. Тараса Шевченка, Каф. міжнар. права. - Київ : К.I.С., 2014. - 687 c.

2. De Nes M. (2015), "The ESM and the Principle of Transparency”, Perspectives on Federalism, vol. 7, p. 128 141.

3. Lodge J. (1994), "Transparency and Democratic Legitimacy”, Journal of Common Market Studies, XXXII (3), - P. 343-368. 
4. Craig P. (2012), EU Administrative Law, Oxford University Press, Oxford, UK.

5. Santini A. (2004), Il principio di trasparenza nell'ordinamento dell'Unione europea, Giuffrè, Milano, IT.

6. Головатий C. Верховенство права. Книга друга. Від доктрини до принципу / С. Головатий. - К.: Фенікс, 2006. - $759 \mathrm{c}$.

7. Чуклинов A. E. "Прозрачная" государственная политика: некоторые проблемы теории и практики / А. Е. Чуклинов // Вестн. Рос. ун-та дружбы народов. - 2006. - № 8. C. 44-50.

8. Березовська I. А. Концепція прозорості в Угоді про асоціацію між Україною та Європейським Союзом / I. А. Березовська // Право України : Юрид. журн. - 2015. - № 8. C. 53-64.

9. Ібрагімова I. М. Прозорість влади. Основи забезпечення інформаційної взаємодії державних органів 3 громадськістю : презентац. схеми / I. М. Ібрагімова. - К. : ПРООН, 2002. - $30 \mathrm{c}$.

10. Мельниченко В. I. Прозорість і відкритість державного управління як чинники його стабілізації / В. I. Мельниченко // Вісн. Нац. акад. держ. упр. при Президентові України. - 2003. - № 4. - С. 4855.

11. Мельниченко В. I. Прозорість і відкритість публічного управління як об'єкт законодавчого регулювання / B. I. Мельниченко // Державне управління: теорія і практика. 2007. - № 1. - [Електронний ресурс]. - Режим доступу: http://www. nbuv.gov.ua/e-journals/DUTP/20071/txts/07mviozr.htm

12. Гудима Н. Принципи відкритості і прозорості та їх реалізація у державному управлінні України / Н. Гудима // Вісн. Нац. акад. держ. упр. при
Президентові України. - 2005. № 3. - С. 77-83.

13. Балкин Дж. Как мас-медиа могут симулировать политическую прозрачность [Электронный ресурс] / Дж. Балкин. - Режим доступа: http://dialogs.org.ua/crossroad_full. php?m_id=9837

14. Гриияк I. Основні принципи права Свропейського Союзу та їх застосування в державному управлінні / I. Грицяк // Вісн. Нац. акад. держ. упр. при Президентові України. 2004. - № 3. - С. 43-50.

15. Рижко B. A. Концепція як форма наукового знання. - К., 1995. - 212 с.

16. Абеляр П. Логика “для начинающих” / П. Абеляр. Теол. трактаты / Пер. с франц. - Мосва, 1995.

17. Compact Oxford English Dictionary of Current English [Електронний pecypc]. - Режим доступу: http:// www.askoxford.com/results

18. Cambridge Advanced Learner's Dictionary [Електронний ресурс]. Режим доступу: http://dictionary. cambridge.org/results.asp

19. Великий тлумачний словник сучасної української мови / уклад. і голов. ред. В. Т. Бусел. - К. : [б. в.] ; Ірпінь : Перун, 2005. - 1728 с.

20. Социология : энциклопедия / сост.: А. А. Грицанов, В. Л. Абушенко, Г. М. Велькин. - Минск : Кн. дом, 2003. - 1312 c.

21. Галкин Д. Виртуальный дискурс в культуре постмодерна / Д. Галкин // Критика и семиотика : сб. науч. тр. - Томск : Изд-во Томск. гос. ун-та, 2000. - Вып. 1-2. C. 26-34.

22. Горинг Г. Право Европейского Союза / Г. Горинг, О. Витвицкая. СПб. : Питер, 2005. - 256 с.

23. Кернз В. Вступ до права Свропейського Союзу: навч. посіб. : пер. 3 англ. / В. Кернз. - К. : Знання, КОО, 2002. - 381 c. 
24. Право Європейського Союзу: навч. посіб. / За заг. ред. Р. А. Петрова. 3-тє вид., змін. і допов. - К.: Істина, 2010. - 376 c.

25. Задорожній О. Українська революція гідності, агресія РФ і міжнародне право: кол. монографія / Упоряд. О. Задорожний. - К.: К.І.С., 2014. $997 \mathrm{c}$.

26. FosterN. (2000), EC Law, Oxford Univ. Press, Oxford, UK.; Horspool, M. (2006), European Union Law, Oxford Univ. Press, Oxford, UK; Tridimas, T. (1997), The General Principles of EC Law, Oxford Univ. Press, Oxford, UK; Usher, J. F. (1998), General Principles of EC Law, Lonqman, London, UK.

27. Функціонування Сдиного веб-порталу використання публічних ко- штів (C-Data): навч.-метод. посіб. / B. В. Таран, В. А. Тарнай, В. М. Мазярчук, А. Б. Розлуцька; за ред. В. Тарана. - К.: Центр політ. студій та аналітики, 2016. - 40 с.

28. Рішення Міжнародного наукового конгресу "Інформаційне суспільство в Україні” (29 жовтня 2013 р., м. Київ) [Електронний ресурс]. Режим доступу: http://congress.ogp. gov.ua/content

29. Поради для початківців в громадській діяльності / Упоряд.: О. Глєбушкіна, Г. Качура. - Херсон: МО "Нова генерація", 2015. - 144 с.

30. Офіційний веб-портал ФАТФ: http://www.fatf-gafi.org/publicat ions $/$ ?hf $=10 \& b=10 \& s=\operatorname{desc}($ fatf releasedate) 